\title{
Influence of titanium dioxide modification on the antibacterial properties
}

\author{
Paulina Rokicka ${ }^{1}$, Agata Markowska-Szczupak ${ }^{1 *}$, Łukasz Kowalczyk ${ }^{1}$, Ewa Kowalska ${ }^{2}$, \\ Antoni W. Morawski ${ }^{1}$ \\ ${ }^{1}$ West Pomeranian University of Technology, Szczecin, Institute of Chemical and Environment Engineering, \\ ul. Pułaskiego 10, 70-322 Szczecin, Poland \\ ${ }^{2}$ Hokkaido University, Institute for Catalysis, North 21, West 10, Sapporo 001-0021, Japan \\ "Corresponding author: e-mail: agata@erb.pl
}

\begin{abstract}
Antibacterial properties of 15 titania photocatalysts, mono- and dual- modified with nitrogen and carbon were examined. Amorphous $\mathrm{TiO}_{2}$, supplied by Azoty Group Chemical Factory Police S.A., was used as titania source $\left(\mathrm{Ar}-\mathrm{TiO} \mathrm{O}_{2}, \mathrm{C}-\mathrm{TiO}_{2}, \mathrm{~N}-T i O_{2}\right.$ and $\mathrm{N}, \mathrm{C}-\mathrm{TiO}_{2}$ calcined at $300^{\circ} \mathrm{C}, 400^{\circ} \mathrm{C}, 500^{\circ} \mathrm{C}, 600^{\circ} \mathrm{C}, 700^{\circ} \mathrm{C}$ ). The disinfection ability was examined against Escherichia coli K12 under irradiation with UV and artificial sunlight and in dark conditions. It has been found the development of new photocatalysts with enhanced interaction ability with microorganisms might be a useful strategy to improve disinfection method conducted under artificial sunlight irradiation. The efficiency of disinfection process conducted under artificial sunlight irradiation with carbon $\left(\mathrm{C}-\mathrm{TiO}_{2}\right)$ and carbon/nitrogen $\left(\mathrm{N}, \mathrm{C}-\mathrm{TiO}_{2}\right)$ photocatalysts was similar as obtained under UV irradiation. Furthermore, during dark incubation, any toxicity of the photocatalyst was noted.
\end{abstract}

Keywords: antibacterial properties, Escherichia coli K12, modified photocatalysts, titanium dioxide, visibleresponsive photocatalysts.

\section{INTRODUCTION}

Almost one-fifth of the world population lives in areas of physical scarcity of fresh water, and additionally one quarter of humanity is lacking of basic sanitation systems. It is estimated that poor quality of water is one of the leading causes of people death in the developing countries, where the microbial pollution is considered to be of serious health concern. According to World Health Organization (WHO) nearly 3.4 million people die each year of waterborne diseases - an illness commonly caused by fecal contamination of water. The mortality of children under the age of five is the highest (6.000 deaths per day). Moreover, increasing appearance of antibiotic-resistant bacteria has been reported ${ }^{1}$.

The situation is only expected to worsen, due to global climate changing, population growth and inefficient use of existing resources restricting the amount of water available to people ${ }^{2}$. With increasing microbial contamination of water new and more potent antibacterial agents and materials are needed.

Water disinfection is a process of removal, deactivation or killing of living pathogens, including viruses, bacteria and protozoa. Disinfection methods are not forceful as sterilization since resistant bacterial spores are not eliminated from water ${ }^{\mathbf{1}, 3}$. Moreover, the conventional methods of water disinfection are not completely effective and they present many drawbacks. Chlorination gives relatively low protection against protozoa and requires usage of chemicals which can form carcinogenic and toxic chlorine by-product, e.g., trihalomethanes and haloacetic acids formed from the reaction of chlorine with natural organic matters in water ${ }^{4}$. Ozonation, one of the advanced oxidation processes (AOPs, in-situ generating hydroxyl radicals), is very efficient, but has a few major drawback such as ozone instability (must be generated immediately before use), high cost of equipment and complicated operating systems 5 . Whereas, water disinfection by UV-irradiation (another AOP) does not prevent bacterial regrowth after the removal of UV-light source ${ }^{2}$.
Therefore, very effective, environmentally friendly and cost effective processes are in greater demand. It is proposed that the photocatalytic oxidation with titanium dioxide (also AOP) fulfills above mentioned tasks.

Titanium dioxide has attracted tremendous attention due to its high photoreactivity, physicochemical stability, market accessibility (there are many manufactures in the world) and affordable prices. The well-known mechanism of $\mathrm{TiO}_{2}$ photocatalytic degradation of organic compounds involves generation of reactive oxygen species (ROS). The potential applications of the technology include organic matter, anthropogenic and natural organic contaminants (e.g. pesticides, surfactants, organic fertilizers), and degradation in various homogeneous and heterogeneous systems $^{6-8}$. Over the last 10 years a lot of reviews with the topic of photocatalytic disinfection of water have been published ${ }^{2,3,9-11}$. Although the antibacterial properties of $\mathrm{TiO}_{2}$ are well documented, there are difficulty in its application since photocatalytic disinfection requires UVA irradiation $(\lambda=320-400 \mathrm{~nm})$ and relatively long inactivation times (e.g., 90 and 130 minutes for achieving $1 \mathrm{log}$ inactivation of Escherichia coli and bacteriophage MS2, respectively ${ }^{12}$ ). It has been estimated that ultraviolet radiation $(\lambda<400 \mathrm{~nm})$ contributes less than $4 \%$ of whole incoming solar radiation, therefore development of visible light active photocatalyst is major challenge ${ }^{13}$. The effective utilization of the visible light $(50 \%$ of solar spectrum) is main aim of study conducted by many research teams. A numerous modification techniques, which seem to be promising for $\mathrm{TiO}_{2}$ band-gap narrowing and shift the light absorption capacity towards visible wavelengths have been proposed ${ }^{14-16}$. The titania modified with noble metals (e.g. Au, Ag), metal oxides (e.g. $\mathrm{ZnO}, \mathrm{WO}_{3}, \mathrm{SiO}_{2}, \mathrm{CrO}$ ) and non-metals e.g. $\mathrm{S}, \mathrm{C}$, $\mathrm{N}$ are most often investigated photocatalysts ${ }^{16-19}$.

In the present study, the antibacterial properties of titania photocatalysts modified with nitrogen and carbon under UV and artificial sunlight irradiation have been examined. There are only a few studies on water disinfection on visible active titania photocatalysts modified 
with nitrogen and/or carbon. The aim of this study was to assess the role of modifiers and post-treatment conditions (temperature of calcination) in microbial inactivation mechanisms. Escherichia coli K12 was chosen as an indicator microorganism in photocatalytic water disinfection systems ${ }^{3,10}$.

\section{EXPERIMENTAL}

\section{Material}

An amorphous $\mathrm{TiO}_{2}$ supplied by Azoty Group Chemical Factory Police S.A., Poland was used as a starting material. Fifteen modified titania by nitrogen, carbon and nitrogen/carbon were prepared in Institute of Chemical and Environment Engineering, West Pomeranian University of Technology in Szczecin (Poland). In order to modify, $20 \mathrm{~g}$ of $\mathrm{TiO}_{2}$ suspended in water was placed in a tubular furnace. Modification was conducted in onestep process with benzene (Sigma-Aldrich Co., USA) and gaseous ammonia (Messer, Poland) as carbon and nitrogen precursors respectively. Samples were heated to desired temperature in inert gas-argon (Messer, Poland) and calcined at $300,400,500,600$ and $700^{\circ} \mathrm{C}\left(\mathrm{Ar}-\mathrm{TiO}_{2}\right)$ in the presence of ammonia $\left(\mathrm{N}-\mathrm{TiO}_{2}\right)$, benzene $\left(\mathrm{C}-\mathrm{TiO}_{2}\right)$ and ammonia with benzene $\left(\mathrm{N}, \mathrm{C}-\mathrm{TiO}_{2}\right)$ for 4 hours. Then samples were cooled down to room temperature in an argon atmosphere. After that samples were rinsed with water and dried for $12 \mathrm{~h}$ at $100^{\circ} \mathrm{C}$ to remove residual ammonia. Photocatalysts calcined in an argon atmosphere were regarded as a control $\left(\mathrm{Ar}-\mathrm{TiO}_{2}\right)$ for nitrogen $(\mathrm{N}$ $\left.\mathrm{TiO}_{2}\right)$, carbon $\left(\mathrm{C}-\mathrm{TiO}_{2}\right)$, and nitrogen/carbon co-modified $\left(\mathrm{N}, \mathrm{C}-\mathrm{TiO}_{2}\right)$ photocatalysts. The phase characteristics of starting $\mathrm{TiO}_{2}$ and $\mathrm{N}^{-} \mathrm{TiO}_{2}, \mathrm{C}-\mathrm{TiO}_{2}$ and co-modified N,C$\mathrm{TiO}_{2}$ calcined at different temperatures was investigated by XRD analysis. The BET specific surface areas were calculation on the basis of the $\mathrm{N}_{2}$ adsorption measurements conducted at $77 \mathrm{~K}$ using a Quadrasorb SI analyzer (Quantachrome Instruments, USA).

\section{Bacterial inactivation}

Glass beakers of $25 \mathrm{~mL}$ were used as reactors. The experiments were carried out under UVA (six bulbs 20 W Philips) or artificial sunlight (one bulb 300 W OSRAM Ultra Vitalux) irradiation. The emission spectra of artificial sunlight and UV sources were presented in previous papers ${ }^{19}$. The radiant flux was monitored with a Radiation Intensity Meter LB901/WCM3 \& PD204AB cos. sensor meter. The distance between the solution and the light source was fixed at ca. $15 \mathrm{~cm}$. The suspension was continuously stirred (using a magnetic stirrer at speed of $250 \mathrm{rpm}$ ) throughout the experiment to ensure homogeneity.

Bacteria Escherichia coli strain K12 (ACCT 25922) was used for study. Before the experiments, bacteria were inoculated into Enriched Broth (Biocorp, Poland) and were cultured at $37^{\circ} \mathrm{C}$ for $24 \mathrm{~h}$. The cell concentration of inoculum was adjusted to final cell density of 1.0 in MacFarland standard (bioMérieux, Poland) equivalent to $3.0 \times 10^{8} \mathrm{CFU} / \mathrm{ml}$. Five $\mu \mathrm{L}$ of the bacterial suspension was added into the reactor which contained $10 \mathrm{~mL}$ $\mathrm{NaCl}$ solution $(0.9 \%)$ and $0.1 \mathrm{~g} \times \mathrm{L}^{-1}$ photocatalyst. The reaction mixture was illuminated with UVA or artificial sunlight for $45 \mathrm{~min}$. Samples were collected in every $15 \mathrm{~min}$. The control experiments in darkness and for $\mathrm{NaCl}$ solution were also performed. Serial dilutions were prepared in saline solution $(0.9 \%)$. The samples were placed on Plate Count Agar (PCA agar, BTL, Poland). The plates were incubated for $24 \mathrm{~h}$ at $37^{\circ} \mathrm{C}$ and then colony forming unit $(\mathrm{CFU} / \mathrm{mL})$ was counted.

Statistical analysis of obtained results was conducted using Excel spreadsheet and Statistica 8.0. The comparisons among means and the statistical significance of differences between means were evaluated by Tukey's test at $\mathrm{P} \leq 0.05$.

\section{RESULTS}

The precise characteristic of modified titania photocatalysts with carbon, nitrogen and carbon and nitrogen will be presented in our further papers. Here, only data essential for interpretation of microbiological results are presented in Figure 1. It is clear that properties of photocatalysts, such as anatase content (a), anatase crystallite size (b), specific surface area (c) and the content of modifiers (d), differ significantly among the samples. The photocatalysts calcined at $300^{\circ} \mathrm{C}$ consist of predominantly anatase of small crystallites (9-10 $\mathrm{nm})$, and thus with large specific surface area (182-194 $\mathrm{m}^{2} / \mathrm{g}$ ). On the contrary, calcination at $700^{\circ} \mathrm{C}$ results in significant growth of crystals reaching $82 \mathrm{~nm}$ (more than 8 times larger crystallite size than at lower calcination temperature), and a decrease in specific surface area (16.4 smaller BET, i.e., $12 \mathrm{~m}^{2} / \mathrm{g}$ and $15 \mathrm{~m}^{2} / \mathrm{g}$ for $\mathrm{N}^{-\mathrm{TiO}_{2}}$ and $\mathrm{N}, \mathrm{C}-\mathrm{TiO}_{2}$, respectively). As expected, the contribution of rutile phase (6-44.7\%) increases with an increase in calcination temperature (Fig. 1a) since rutile is the most stable polymorph of titania. In consequence, different antibacterial activities are expected for titania photocatalysts prepared at varied calcination temperature.

The most important structural properties of examined photocatalyst appear to correlate with calcination temperature, which strongly determines the structural composition. Due to this reason the antibacterial activity of photocatalyst is presented for individual calcination temperature. The antibacterial properties of unmodified $\left(\mathrm{Ar}-\mathrm{TiO}_{2}\right)$ and modified $\left(\mathrm{N}-\mathrm{TiO}_{2}, \mathrm{C}-\mathrm{TiO}_{2}\right.$ and $\left.\mathrm{N}, \mathrm{C}-\mathrm{TiO}{ }_{2}\right)$ photocatalysts as function of time are demonstrated in Figsures 2-4. Under UVA irradiation, almost all examined Ar-TiO $, 2-\mathrm{N}_{2} \mathrm{TiO}_{2}, \mathrm{C}-\mathrm{TiO}_{2}$ and $\mathrm{N}, \mathrm{C}-\mathrm{TiO}_{2}$ photocatalysts presented similar antibacterial activity. After $30 \mathrm{~min}$ of irradiation, 100\% of Escherichia coli was killed, with the exception of the control sample calcined in argon $\left(\mathrm{Ar}-\mathrm{TiO}_{2}\right)$ at the highest temperature of $700^{\circ} \mathrm{C}$, which needed longer irradiation time of $45 \mathrm{~min}$ (Fig. 2e).

In Figure 2 the results obtained in experiments conducted under UV irradiation are presented. All examined photocatalyst (unmodified and $\mathrm{C}$ - and $\mathrm{N}$-modified and $\mathrm{C}, \mathrm{N}$ co-modified) have antibacterial high activity. The bacterial killing process started in $15 \mathrm{~min}$ and increased with further increase in exposure time. After 30 minutes the total reduction count in all PCA plates was observed.

Figure 3 shows E. coli inactivation in the presence of examined photocatalyst under artificial sunlight (VIS) irradiation. The best activity towards $E$. coli possessed carbon modified photocatalyst $\left(\mathrm{C}-\mathrm{TiO}_{2}\right)$ calcined at $700^{\circ} \mathrm{C}$ 
a)

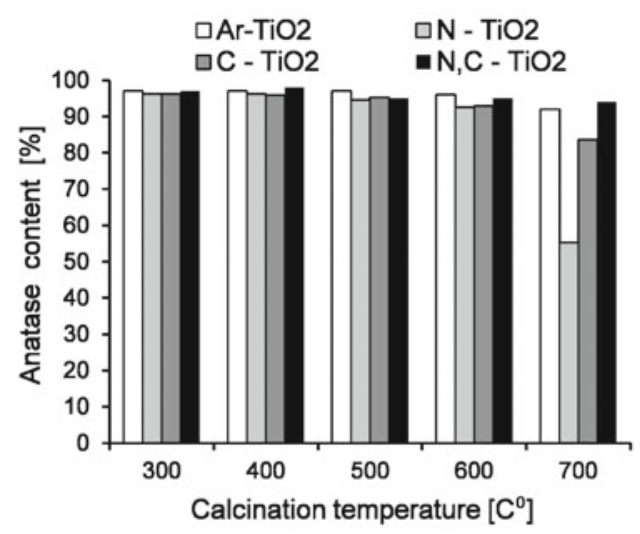

c)

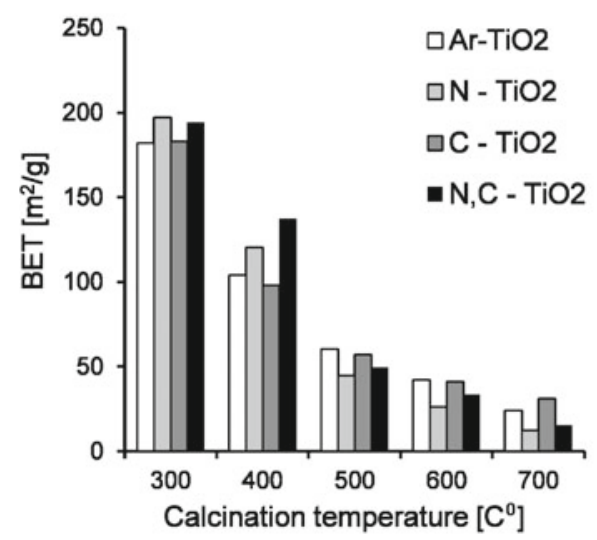

b)

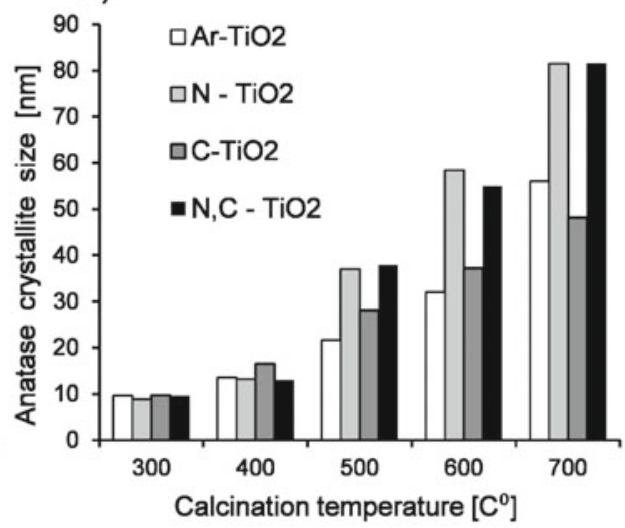

d)

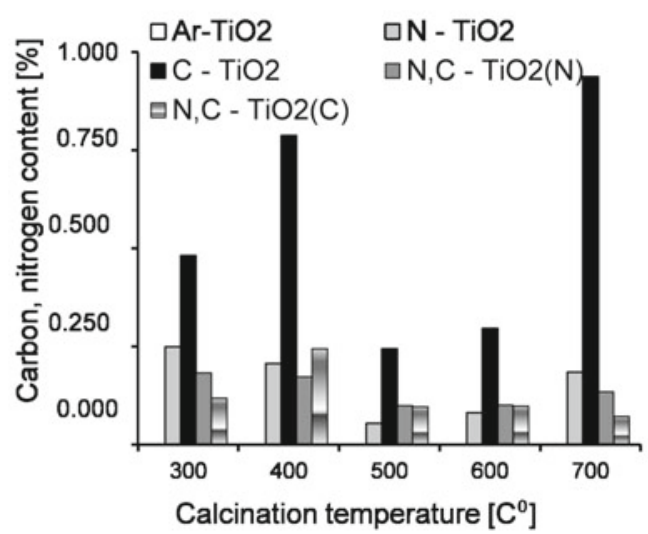

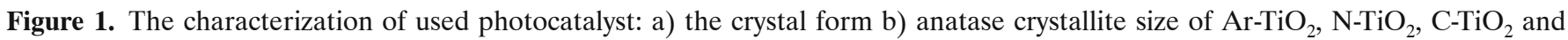
$\mathrm{NC}_{-\mathrm{TiO}}$ c) BET Ar-TiO $, \mathrm{N}-\mathrm{TiO}_{2}, \mathrm{C}-\mathrm{TiO}_{2}$ and $\mathrm{NC}-\mathrm{TiO}_{2}$ d) nitrogen, carbon content

e)

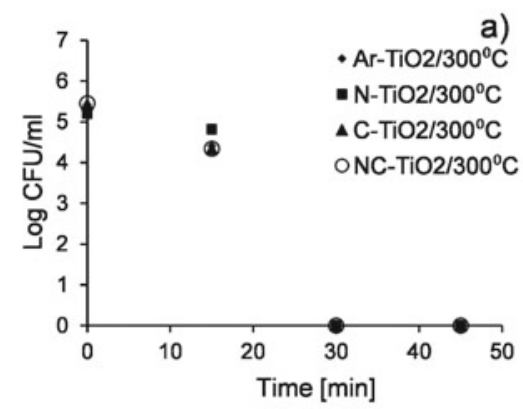

b)

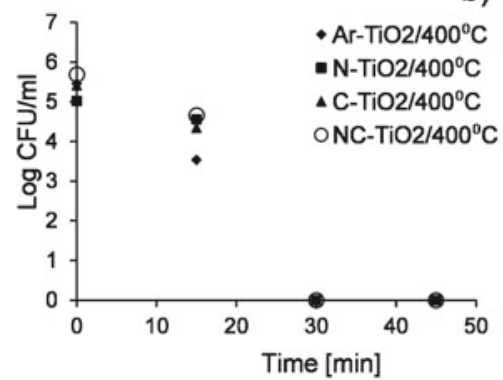

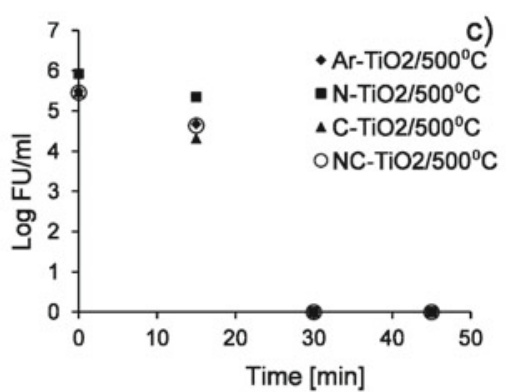

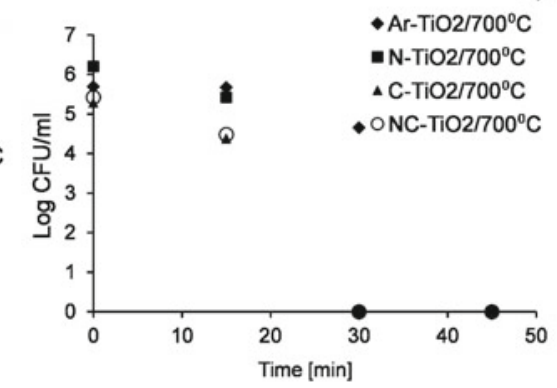

d)

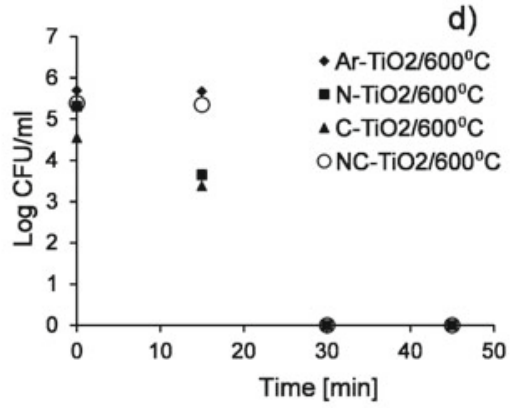

Figure 2. Antibacterial activity of modified titania: calcined in argon $\left(\mathrm{Ar}-\mathrm{TiO}_{2}\right)$ ammonia $\left(\mathrm{N}_{-} \mathrm{TiO}_{2}\right)$, benzene $\left.(\mathrm{C}-\mathrm{TiO})_{2}\right)$ and ammonia with benzene $\left(\mathrm{N}, \mathrm{C}-\mathrm{TiO}_{2}\right)$ atmosphere at $300^{\circ} \mathrm{C}(\mathrm{a}), 400^{\circ} \mathrm{C}(\mathrm{b}), 500^{\circ} \mathrm{C}(\mathrm{c}), 600^{\circ} \mathrm{C}$ (d) and $700^{\circ} \mathrm{C}$ (e) under UV irradiation

(Fig. 3e). No live bacteria cells were found just over 15 min under VIS irradiation. A slight lower antibacterial performance demonstrated other photocatalysts: $\mathrm{C}-\mathrm{TiO}_{2}$ and $\mathrm{N}, \mathrm{C}-\mathrm{TiO}_{2}$ obtained at $300^{\circ} \mathrm{C}$ and $400^{\circ} \mathrm{C}$ temperatures,
C-TiO ${ }_{2}$ calcined at $600^{\circ} \mathrm{C}$ and $\mathrm{N}-\mathrm{TiO}_{2}$ calcined at $700^{\circ} \mathrm{C}$ (Fig. 3a-e).

To better understand photocatalytic effect, control experiments were carried out in the darkness. Under these conditions almost all examined photacatalysts did 

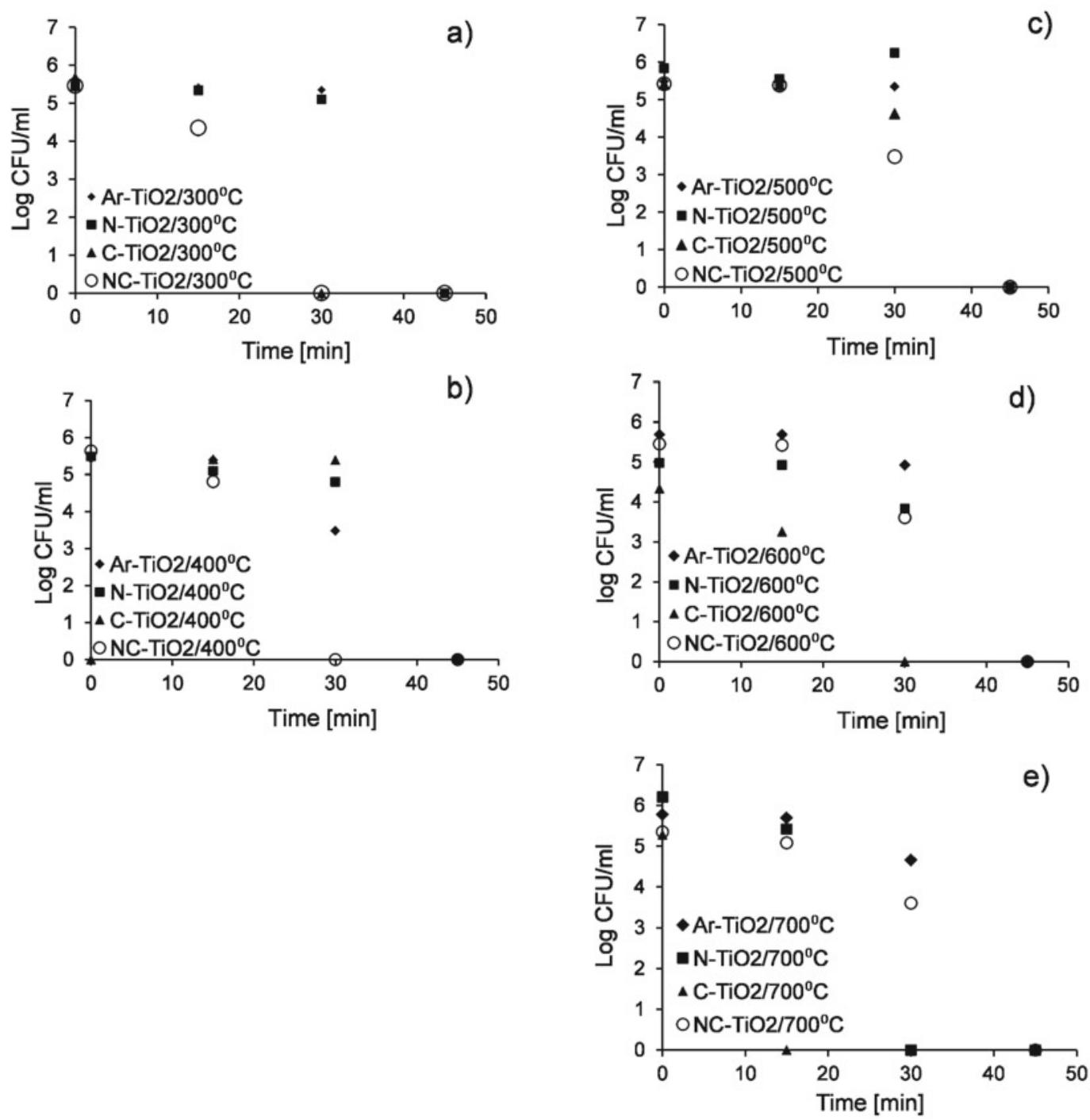

Figure 3. Antibacterial activity of modified titania: calcined in argon $\left(\mathrm{Ar}-\mathrm{TiO}_{2}\right)$ ammonia $\left(\mathrm{N}-\mathrm{TiO}_{2}\right)$, benzene $\left(\mathrm{C}-\mathrm{TiO}_{2}\right)$ and ammonia with benzene $\left(\mathrm{N}, \mathrm{C}-\mathrm{TiO}_{2}\right)$ atmosphere at $300^{\circ} \mathrm{C}(\mathrm{a}), 400^{\circ} \mathrm{C}(\mathrm{b}), 500^{\circ} \mathrm{C}(\mathrm{c}), 600^{\circ} \mathrm{C}(\mathrm{d})$ and $700^{\circ} \mathrm{C} \mathrm{(e)} \mathrm{under} \mathrm{artificial} \mathrm{sunlight}$ irradiation

not influence on survival of bacteria (Fig. 4a-e). The only exception was unmodified catalyst $\left(\mathrm{Ar}-\mathrm{TiO}_{2}\right)$ calcined at $400^{\circ} \mathrm{C}$. After 45 minutes of incubation the percentage of killed bacteria achieved approx. 17\% (Fig. 4b).

To include the influence of irradiation type, the experiments without photocatalysts under UV and artificial sunlight irradiation were also conducted. It was found that both kind of irradiations did not cause significant changes in bacteria survival (Fig. 5).

To analyze the influence of calcination temperature on the antimicrobial performance, the bacterial reduction rate after 15 min from start of experiments was calculated and compared by Tukey's test. It was shown that for unmodified samples $\left(\mathrm{Ar}-\mathrm{TiO}_{2}\right)$, the interaction between photocatalysts structural characteristic (closely related to preparation temperature) and bacteria destroying properties was statistically significant at $\mathrm{P} \leq 0.05$ (Fig. 6). Unexpectedly, after $15 \mathrm{~min}$ of UV irradiation the similar high antimicrobial performance was obtained by photocatalysts prepared at $400^{\circ} \mathrm{C}$ and $600^{\circ} \mathrm{C}$, which vary in specific surface area (BET) and anatase crystallite size (Fig. 1). In turn, under artificial sunlight irradiation different photocatalysts (treated at $500^{\circ} \mathrm{C}$ and $700^{\circ} \mathrm{C}$ ) exhibited higher antibacterial properties (Fig. 6).
Since 30 minutes of UV irradiation resulted in complete bacteria inactivation (Fig. 1), to estimate the influence of nitrogen content on the antimicrobial properties, the bacterial reduction rate after $15 \mathrm{~min}$ of UV irradiation was compared by Tukey's test. It was found out that nitrogen content is particularly important in nitrogen modified photocatalyst $\mathrm{N}_{-} \mathrm{TiO}_{2}$ (Fig. 7a). The highest antibacterial properties had titania calcined at $600^{\circ} \mathrm{C}$ and characterized by relatively low $\mathrm{N}$-content $(0.081 \%)$. All observed differences were statistically significant. The number of killed bacteria decreased with decreasing nitrogen content. In contrary nitrogen content in carbon co-modified photocatalysts did not influenced on antibacterial performance. The only exception was $\mathrm{N}, \mathrm{C}-\mathrm{TiO}_{2}-600^{\circ} \mathrm{C}$ which possessed the lowest bacterial reduction (Fig. 7b).

The similar analysis was carried out for experiments carried out under artificial sunlight irradiation. The results were presented in Fig. 8(a,b). Only in Figure 8b there is a clearly defined pattern and this can mean that increasing nitrogen content in $\mathrm{N}-\mathrm{TiO}_{2}$, and $\left(\mathrm{N}, \mathrm{C}-\mathrm{TiO}_{2}\right)$ co-modified photocatalysts improves antimicrobial performance. Almost all observed differences were statically significant at $\mathrm{P} \leq 0.05$. 

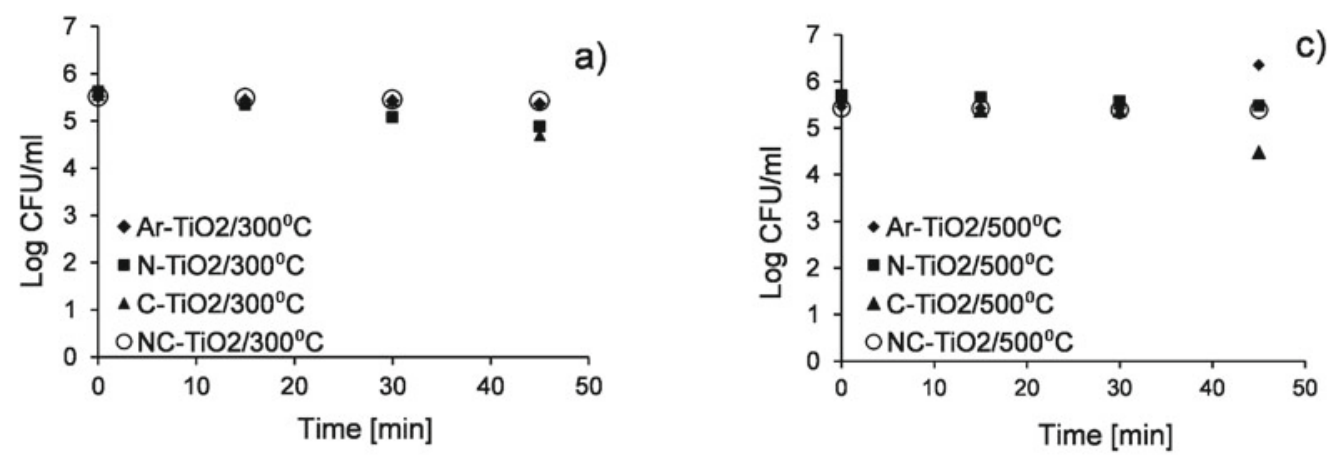

c)
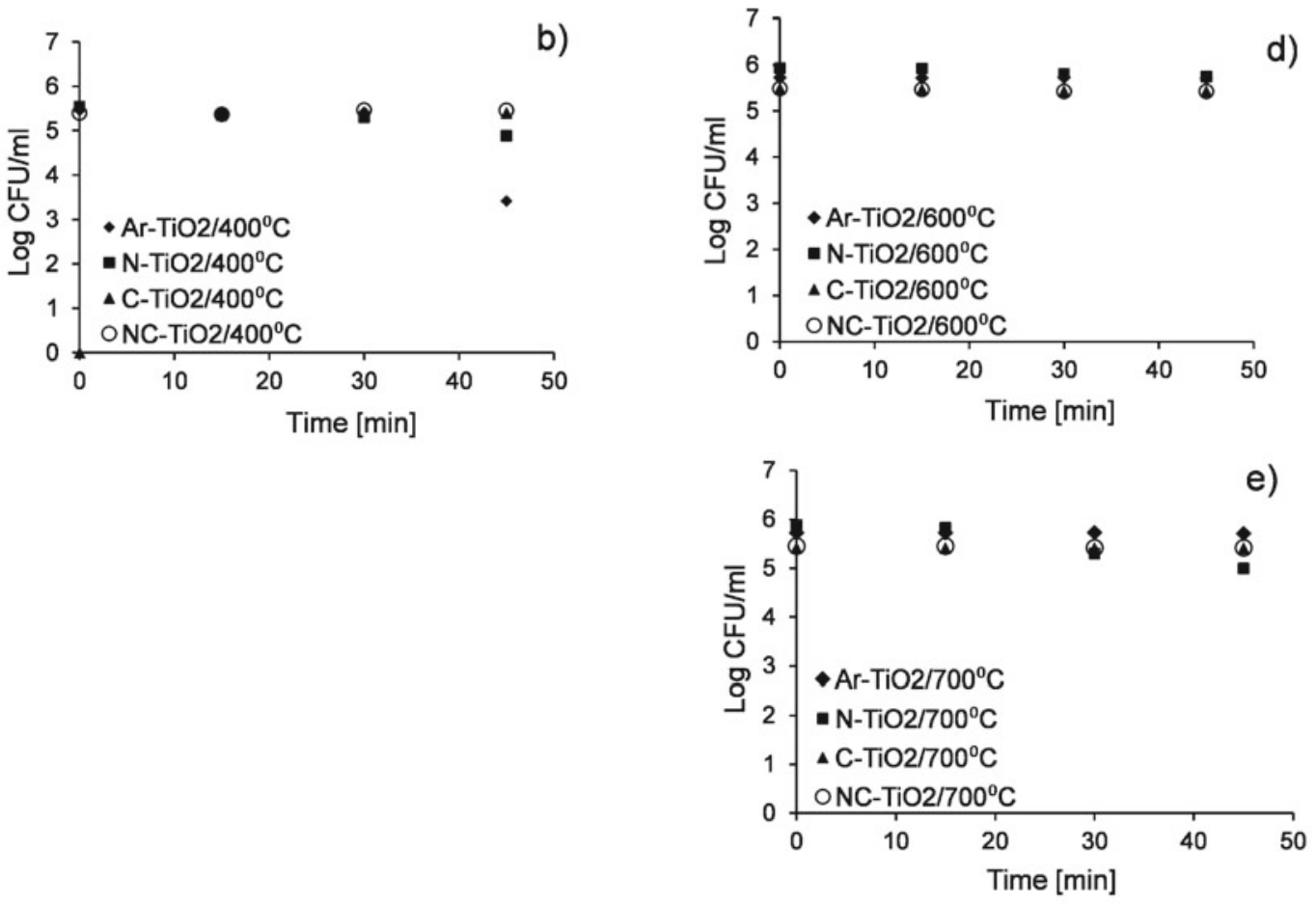

Figure 4. Antibacterial activity of modified titania: calcined in argon $\left(\mathrm{Ar}-\mathrm{TiO}_{2}\right)$ ammonia $\left(\mathrm{N}-\mathrm{TiO}_{2}\right)$, benzene $(\mathrm{C}-\mathrm{TiO})_{2}$ and ammonia

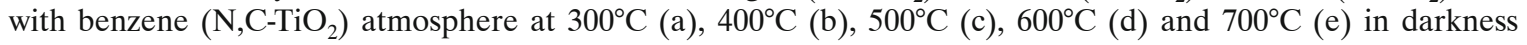

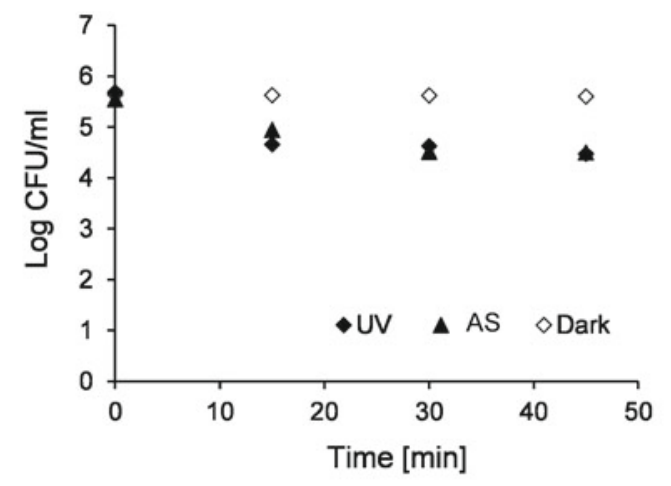

Figure 5. Concentration of bacteria in water under UV or artificial sunlight (AS) irradiation and in dark conditions

To consider the impact of carbon content on the antimicrobial performance, the bacterial reduction rate after $15 \mathrm{~min}$ of UV and artificial sunlight irradiation was calculated and compared by Tukey's test. According to the Figure 9, the carbon content in $\mathrm{C}_{-}-\mathrm{TiO}_{2}$, and $\left(\mathrm{N}, \mathrm{C}-\mathrm{TiO}_{2}\right)$ photocatalysts did not influence significantly on antibacterial performance under UV irradiation. The only one exception was $\mathrm{N}, \mathrm{C}-\mathrm{TiO}_{2}-600^{\circ} \mathrm{C}$ photocatalyst that caused lower bacterial reduction after 15 minutes UV irradiation.

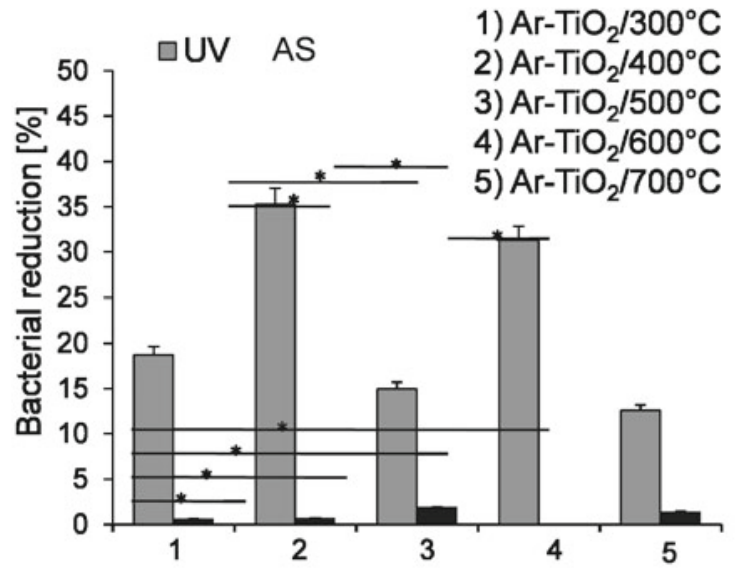

Figure 6. Photocatalytic bacteria reduction of unmodified Ar-TiO ${ }_{2}$ catalysts calcined at different temperatures after 15 min under UV or artificial sunlight (AS) irradiation. *Statistical significance of differences between means obtained for catalysts calcined at different temperatures at $\mathrm{P} \leq 0.05$ (Tukey's test)

On the other hand, the carbon content strongly influenced on bacteria reduction in carbon modified titania under artificial sunlight irradiation (Fig. 10a). The C-TiO -700 photocatalyst characterized by substantially higher carbon content $(0.937 \%)$ caused complete bac- 
a)

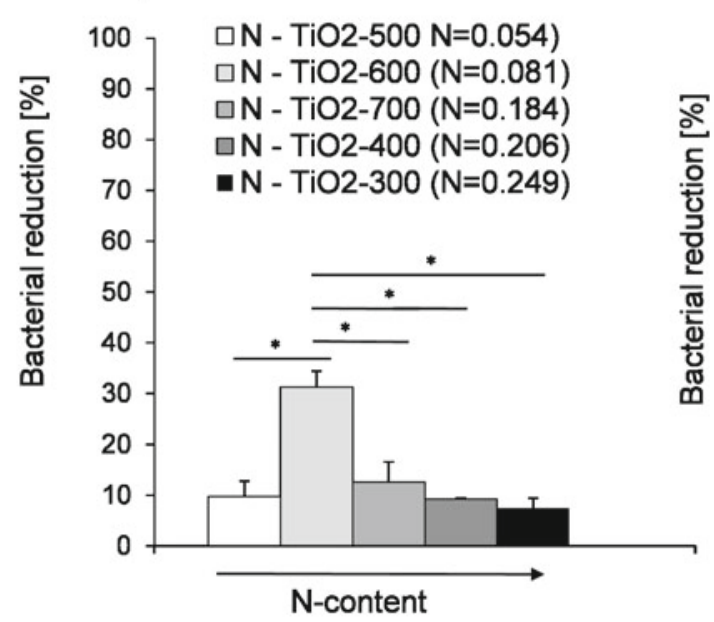

b)

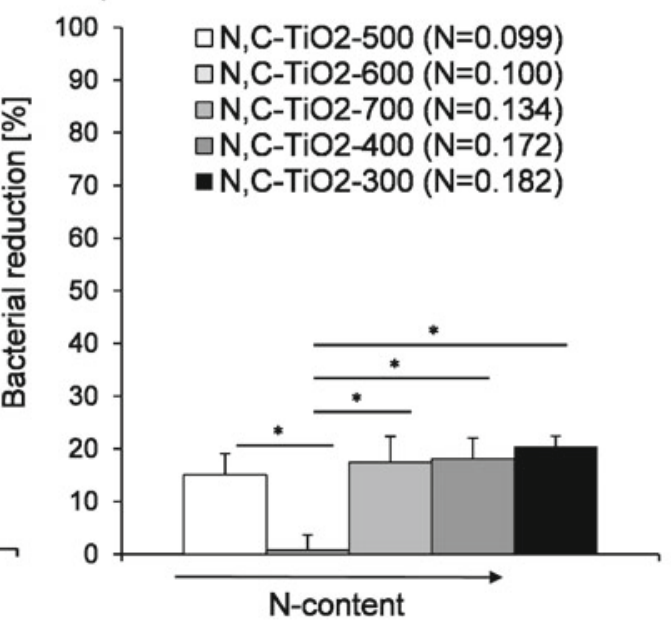

Figure 7. Photocatalytic bacteria reduction obtained for $\mathrm{N}$ and $\mathrm{N}, \mathrm{C}-\mathrm{TiO}_{2}$ catalysts calcined at different temperatures after 15 min under UV irradiation. *Statistical significance of differences between means obtained for catalysts calcined at different $\mathrm{N}$ content (given in parentheses) at $\mathrm{P} \leq 0.05$ (Tukey's test)

a)

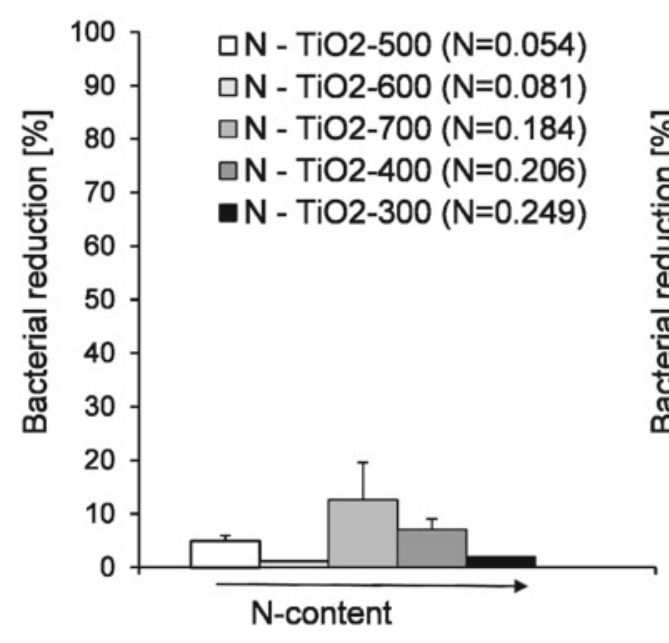

b)

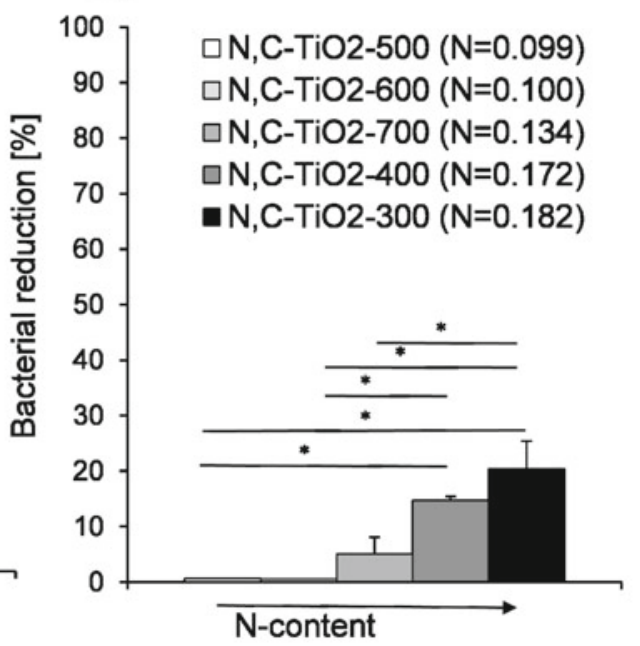

Figure 8. Photocatalytic bacteria reduction obtained for $\mathrm{N}$ and $\mathrm{N}, \mathrm{C}-\mathrm{TiO}_{2}$ catalysts calcined at different temperatures after 15 min under artificial sunlight irradiation. *Statistical significance of differences between means obtained for catalysts calcined at different $\mathrm{N}$ content (given in parentheses) at $\mathrm{P} \leq 0.05$ (Tukey's test)

teria reduction after first $15 \mathrm{~min}$. The carbon content in $\mathrm{N}^{-\mathrm{TiO}_{2}}$, and $\left(\mathrm{N}, \mathrm{C}-\mathrm{TiO}_{2}\right)$ titanias was generally lower than that in $\mathrm{C}-\mathrm{TiO}_{2}$ regardless of the temperature used for calcination. For that reason, influence of carbon content in $\mathrm{N}, \mathrm{C}$ co-modified titania was less important than in $\mathrm{C}$-modified $\mathrm{TiO}_{2}$ (Fig. 10b).

\section{DISCUSSION}

The analysis of the results has shown, that temperature of calcination greatly affected on antibacterial properties of $\mathrm{N}^{-} \mathrm{TiO}_{2}, \mathrm{C}-\mathrm{TiO}_{2}$ and co-modified $\mathrm{N}, \mathrm{C}-\mathrm{TiO}$. The observed differences could arise from the fact that titania phase transformed during heat treatment. At the calcination temperature higher than $600^{\circ} \mathrm{C}$ rutile phase appearance increased. It has been known that anatase particles possess a larger band-gap and a smaller electron effective mass, resulting in the higher mobility of the charge carriers. It caused the increase of reactive oxygen species (ROS) formation. From a toxicological point of view greater generation of ROS and other important characteristics of photocatalyst as its size, surface area, crystallinity, shape, solubility and agglomeration/aggregation state are important. However, it is also believed that the co-presence of both anatase and rutile phases is important for photacatalytic efficiency ${ }^{\mathbf{1 9}, \mathbf{2 1}}$. Better bacterial reduction was achieved for photocatalysts, which consisted from 3.0 to $4.1 \%$ of rutile (from 97 to 95.9 anatase phase respectively) than for single-phase titania. The rutile content over 16.4 is considered to be the cause of reduced antibacterial properties demonstrated for samples prepared at $700^{\circ} \mathrm{C}$.

No clear correlation between increasing calcinations temperature and antibacterial properties was observed for unmodified photocatalyst $\left(\mathrm{Ar}-\mathrm{TiO}_{2}\right)$. These observation was made after 15 minutes from start of photocatalytic process, which indicated the existence of an induction period. It has been known that during the first minutes bacteria use self-defence and auto-repair mechanisms to protect against the active species generated under irradiation. Oxidation of outer membrane begins gradually but not sufficiently to cause serious damage to the 
a)

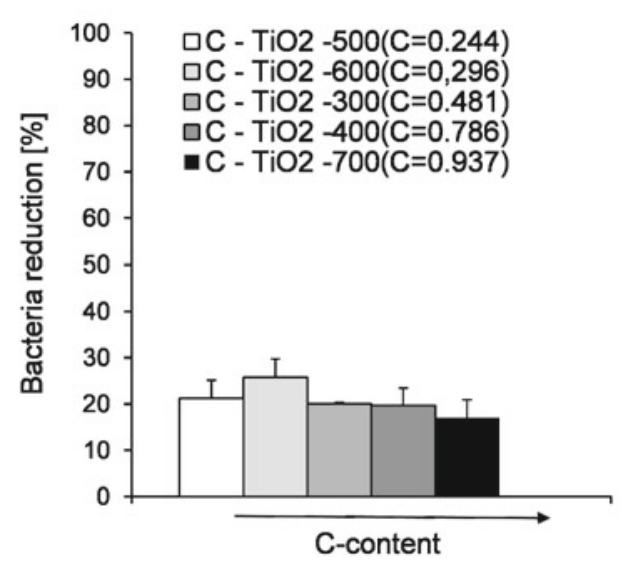

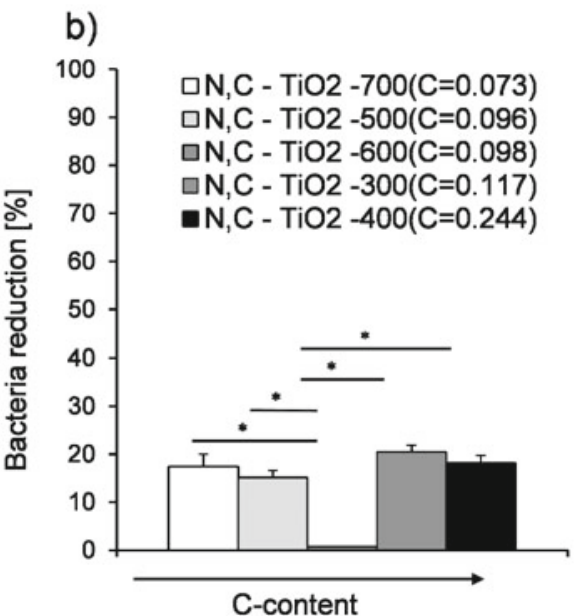

Figure 9. Photocatalytic bacteria reduction obtained for $\mathrm{C}$ and $\mathrm{N}, \mathrm{C}-\mathrm{TiO}_{2}$ catalysts calcined at different temperatures after 15 min under UV irradiation. *Statistical significance of differences between means obtained for catalysts calcined at different $\mathrm{C}$ content (given in parentheses) at $\mathrm{P} \leq 0.05$ (Tukey's test)

a)

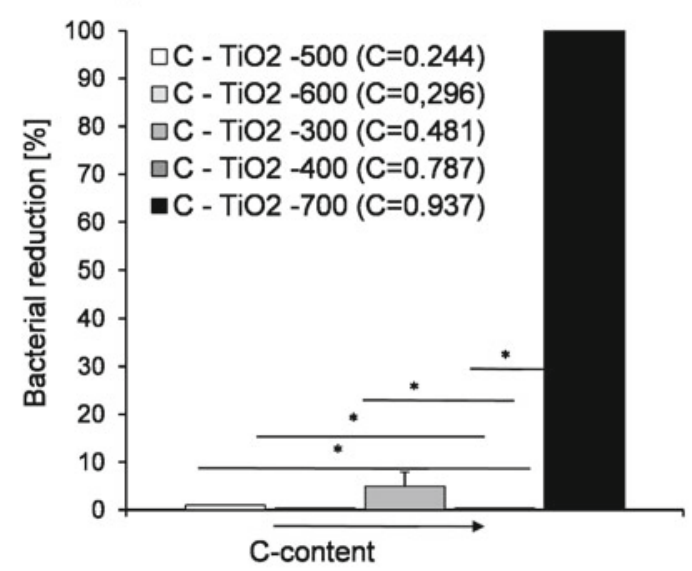

b)

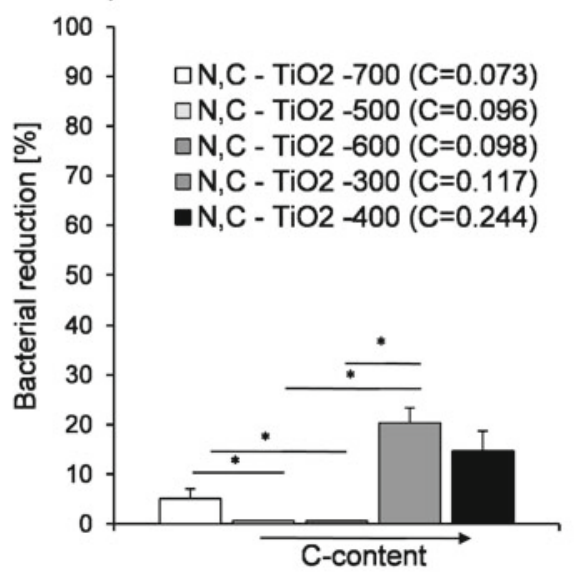

Figure 10. Photocatalytic bacteria reduction obtained for $\mathrm{C}$ and $\mathrm{N}, \mathrm{C}-\mathrm{TiO}_{2}$ catalysts calcined at different temperatures after 15 min under artificial sunlight irradiation. *Statistical significance of differences between means obtained for catalysts calcined at different $\mathrm{C}$ content (given in parentheses) at $\mathrm{P} \leq 0.05$ (Tukey's test)

bacterial cells ${ }^{22}$. It was assumed that better antibacterial properties presented photocatalyst characterized by similar anatase and rutile crystallite sizes. The optimal ratio between rutile and anatase crystallites should be from $1.1\left(\mathrm{Ar}-\mathrm{TiO}_{2}-600^{\circ} \mathrm{C}\right)$ to $2.0\left(\mathrm{Ar}-\mathrm{TiO}_{2}-700^{\circ} \mathrm{C}\right)$.

Our results indicated that visible light was sufficient to activate the photocatalytic process. Under artificial sunlight irradiation the antibacterial efficacy of examined $\mathrm{N}-\mathrm{TiO}_{2}, \mathrm{C}-\mathrm{TiO}_{2}$ and co-modified $\mathrm{N}, \mathrm{C}-\mathrm{TiO}_{2}$ photocatalysts was high. Some of examined photocatalyst $\left(\mathrm{C}-\mathrm{TiO}_{2} \mathrm{~N}, \mathrm{C}-\right.$ $\mathrm{TiO}_{2}$ calcined at 300 and $400^{\circ} \mathrm{C}, \mathrm{C}-\mathrm{TiO}_{2}$ calcined at $600^{\circ} \mathrm{C}$ and $\mathrm{N}^{-\mathrm{TiO}_{2}}$ calcined at $700^{\circ} \mathrm{C}$ ) presented almost the same germ-destroying impact as under UVA irradiation. It means that modification of titania contributed the expected results. It is worth to notice that time required to complete inactivation of $E$. coli was the same as for Ag-doped photocatalyst. According to $\mathrm{Hu}$ et. $\mathrm{al}^{23}$ and Shi et al. $^{24}$, the complete elimination of bacteria occurred after 40 to $60 \mathrm{~min}$ of their contact with $\mathrm{Ag} / \mathrm{AgBr} / \mathrm{TiO}_{2}$ and $\mathrm{Ag} / \mathrm{AgX}-\mathrm{CNTs}$ under artificial sunlight. However, the excellent disinfection activity of Ag modified titania is caused mainly by $\mathrm{Ag}$ itself instead of photocatalytic activity. Due this reason, Ag modified titania very often presents antibacterial activity also in dark conditions. That way the use of silver modified titania photocatalysts have been extensively explored disinfection methods for the potential environmental applications ${ }^{25}$. However, there is lack of consistency in research results concerning the silver self-toxicity ${ }^{26}$. Another very important aspect which should be taken into account is bacterial resistance to silver. Starting to use silver NPs in many products such as: cosmetics (e.g., toothpaste, cloths and pharmaceutical products (e.g. bandage, plaster)) to combat bacteria was presented as a safety and effective alternative to antibiotics, also against multi antibiotic resistant bacteria (e.g. Methicillin-resistant Staphylococcus aureus, MRSA). It is now turning out that sil genes, encoding silver resistance, occurred at a high frequency and were found in e.g. Enterobacter spp., Klebsiella spp., human Escherichia coli. Moreover silver resistant bacteria appear rapidly most frequently in human isolates. For example silver-resistant Enterobacter cloacae strain was isolated from a chronic leg ulcer after only three weeks of treatment with silver-based dressings ${ }^{27}$. For that reason use of silver modified nanomaterials, e.g., titania may affect the bacterial resistance, thereby, can be a limiting factor in development of disinfections technologies. On the contrary, there are no such problems with regard 
to carbon and nitrogen photocatalyst. Although in the presented studies only survival tests were performed, there is no evidence that nitrogen, carbon and nitrogen/ carbon co-modified titanias are harmful for bacteria in dark conditions. The antibacterial activity only under irradiation brought about by desirable modification is beneficial to disinfection processes, as it facilitates controls which mainly occurs in contact with photocatalyst and depends on the source of light. Using carbon and nitrogen for titania surface modification appears to be more safety due to lack of evidence of toxicity induced by mentioned above modifiers. However, the question remains: What is the underlying mechanism of their antibacterial activity? It seems that both temperature treatment and modifier can influence on antibacterial properties of modified titania. Due to different surface coatings, photocatalysts have a preferential interaction with bacterial membrane components. By confocal Raman mapping techniques, Cheng et al. ${ }^{27}$ proved that better bacterial interaction was associated with better pathogenkilling performance. For this reason antibacterial activity of modified titania might be significantly enhanced by carbon. Our results only partially confirmed this hypothesis. When the carbon content is high $(\mathrm{C}=0.937 \%)$ and there is no nitrogen $\left(\mathrm{C}-\mathrm{TiO}_{2}-700\right)$, the complete bacteria reduction is possible after 15 minutes of UV irradiation. On the other hand, this photocatalyst showed considerably stronger antibacterial effects than it might have resulted from anatase crystallite size (relatively big crystallites approx. $48.1 \mathrm{~nm}$ ), active surface area (relatively small approx. $31.0 \mathrm{~m}^{2} / \mathrm{g}$ ). It can be explained by zeta potential, which is changed by carbon or nitrogen modification. Our previous study showed that zeta potentials of the nitrogen modified $\mathrm{TiO}_{2}$ films were negative $(\geq-32$ $\mathrm{mV}$ ), whereas the zeta potential of carbon-modified $\mathrm{TiO}_{2}$ photocatalysts was remarkably higher and amounted to $-1.5 \mathrm{mV}$ or equaled to zero ${ }^{28-29}$. The zeta potential of $\mathrm{TiO}_{2}$ surfaces do not only play a crucial role in the controlling the adsorption properties of aqueous contaminants, but also can influence on adhesion of the bacteria. Due to the negatively charged $E$. coli outer membrane ${ }^{\mathbf{3 0}}$ particles of photocatalyst are repelled each other that enhanced antibacterial effect, which results in appearance of induction period. On the other hand, the generation of reactive oxygen species (ROS) - the main factor caused oxidative stress in bacteria cells depends on crystal structure and surface area. According to Jiang et al. $^{31}$, ROS generation is associated with the number of defect sites per surface area, and an S-shaped curve was observed as a function of particle size. The ability of titania nanoparticles to generate ROS grows as follows: amorphous $>$ anatase $>$ anatase/rutile mixtures $>$ rutile. Our results indicated that nitrogen and carbon content most strongly influenced on antibacterial properties of titania photocatalyst under artificial sunlight irradiation.

Further studies on relationships between structure and antibacterial activity are needed to explain all possible mechanisms. It was shown that there is lack of correlation between nitrogen, carbon and nitrogen-carbon content and calcination temperature of titania. For this reason a linear correlation between temperature and antibacterial performance was not established. Different results were presented by Cheng et al., who examined the property of $\mathrm{N}$-doped $\mathrm{TiO}_{2}$ films annealed in the range $400^{\circ} \mathrm{C}-600^{\circ} \mathrm{C}^{27}$. Authors suggested the antimicrobial activity of $\mathrm{N}$-doped $\mathrm{TiO}_{2}$ increased slightly with increasing of annealing temperatures.

Unexpectedly, carbon and nitrogen co-modified photocatalyst did not present enhanced antibacterial activity. It was not in accordance with Chen et al. findings ${ }^{32}$ that binary oxide photocatalysts often exhibited higher catalytic activity than predicted from the properties of their components. The difference in the energy level of their conduction bands and valence bands provides rapid separation of the photogenerated electrons and protects against recombination, thus enhancing the generation of photogenerated ${ }^{+} \mathrm{OH}$ radicals. The most effective method for increasing the photocatalytic activity under visible irradiation is co-doping with non-metal and metal ${ }^{33}$. In presen study two non-metals were used, which is likely the main cause lowering the photocatalytic activity. A second reason of low antibacterial performance of $\mathrm{N}, \mathrm{C}-\mathrm{TiO}_{2}$ photocatalysts can originate from lower nitrogen and carbon content in those samples than in single modified photocatalysts $\left(\mathrm{C}-\mathrm{TiO}_{2}\right.$ or $\left.\mathrm{N}-\mathrm{TO}_{2}\right)$. The photocatalyst affinity to bacterial membrane, derived from banning site existing on the photocatalyst surface, is probably reduced.

In conclusion, we found that majority of obtained $\mathrm{C}-\mathrm{TiO}_{2}$, and $\left(\mathrm{N}, \mathrm{C}-\mathrm{TiO}_{2}\right)$ photocatalysts can be used in the sun light settings to reduce the transmission of $E$. coli bacteria from water.

\section{CONCLUSIONS}

Carbon and nitrogen single and dual modified titania photocatalysts obtained during calcination at $300-400^{\circ} \mathrm{C}$ demonstrated satisfactory antibacterial properties towards Escherichia coli bacteria under artificial sunlight irradiation. It was their unique structures (small anatase crystallites) and large active surface area the main factors influenced on antibacterial properties.

\section{ACKNOWLEDGEMENT}

This work was financially supported by project Maestro 3 No. DEC-2012/06/A/ST5/00226 from the National Science Centre (Poland).

\section{LITERATURE CITED}

1. Pigeot-Rémy, S., Simonet, F., Errazuriz-Cerda, E., Lazzaroni, J.C., Atlan, D. \& Guillard, C. (2011). Photocatalysis and disinfection of water: Identification of potential bacterial targets. Appl. Catal., B. 104(3-4), 390-398. DOI: 10.1016/j. apcatb.2011.03.001.

2. Grojec, A. (2015) (Eds.) Progress on sanitation and drinking water - 2015 update and MDG assessment, WHO Press 2015. 3. Wang, W., Huang, G., Yu, J.C. \& Wong, P.K. (2015). Advances in photocatalytic disinfection of bacteria: Development of photocatalysts and mechanisms. J. Environ. Sci. 34, 232-247. DOI: $10.1016 / j . j e s .2015 .05 .003$.

4. Huaa, G. \& Reckhow, D.A. (2007). Comparison of disinfection byproduct formation from chlorine and alternative disinfectants. Water Res. 41(8), 1667-1678. DOI: 10.1016/j. watres.2007.01.032.

5. Gunten, U. (2003). Ozonation of drinking water: Part I. Oxidation kinetics and product formation. Water Res. 37(8), 1443-1467. DOI: 10.1016/S0043-1354(02)00457-8. 
6. Lazar, M.J., Varghese, S. \& Nair, S.S. (2012). Photocatalytic water treatment by titanium dioxide: recent updates. Catalysts 2(4), 527-601. DOI: 10.3390/catal2040572.

7. Nakata, K. \& Fujishima, A. (2012). $\mathrm{TiO}_{2}$ photocatalysis: Design and applications. J. Photochem. Photobiol. C: Photochem. Rev. 13(3), 169-189. DOI: 10.1016/j.jphotochemrev.2012.06.001. 8. Augugliaroa, V., Bellarditaa, M., Loddoa, V., Palmisanoa, G., Palmisanoa, L. \& Yurdakal, S. (2002). Overview on oxidation mechanisms of organic compounds by $\mathrm{TiO}_{2}$ in heterogeneous photocatalysis. J. Photochem. Photobiol. C: Photochem. Rev. 13(3), 224-245. DOI: 10.1016/j.jphotochemrev.2012.04.003.

9. Olmez, H. \& Kretzschmar, U. (2009). Potential alternative disinfection methods for organic fresh-cut industry for minimizing water consumption and environmental impact. Food Sci. Techn. 42(3), 686-693. DOI: 10.1016/j.lwt.2008.08.001.

10. Chong, M.N., Jin, B., Chow, C.W.K. \& Saint, C. (2010). Recent developments in photocatalytic water treatment technology: A review. Water Res. 44(10), 2997-3027. DOI: 10.1016/j. watres.2010.02.039.

11. Mccullagh, C., Robertson, J.M.C., Bahnemann, D.W. \& Robertson, P.K.J. (2007). The application of $\mathrm{TiO}_{2}$ photocatalysis for disinfection of water contaminated with pathogenic microorganism: a review. Res. Chem. Intermed. 33(3), 359-375. DOI: $10.1163 / 156856707779238775$.

12. Malato, S., Fernández-Ibáñez, P., Maldonado, M.I., Blanco, J. \& Gernjak, W. (2009). Decontamination and disinfection of water by solar photocatalysis: Recent overview and trends. Cat. Today 147(1), 1-60. DOI: 10.1016/j.cattod.2009.06.018.

13. Kowalska, E., Mahaney, O.O.P., Abe, R. \& Ohtani, B. (2010). Visible-light-induced photocatalysis through surface plasmon excitation of gold on titania surfaces. Phys. Chem. Chem. Phys. 12, 2344-2355. DOI: 10.1039/B917399D.

14. Wang, P., Huang, B., Qin, X., Zhang, X., Dai, Y., Wei, J. \& Whangbo, M.H. (2008). Ag@AgCl: A highly efficient and stable photocatalyst active under visible light. Angew. Chem. Int. Edit. 47(41), 7931-7933. DOI: 10.1002/anie.200802483.

15. Morawski, A.W., Janus, M., Tryba, B., Inagaki, M. \& Kałucki, K. (2006). $\mathrm{TiO}_{2}$ - anatase modified by carbon as the photocatalyst under visible light. CR Chim. 9(5-6), 800-805. DOI: 10.1016/j.crci.2005.03.021.

16. Zhou, N., Polavarapu, L., Gao, N., Pan, Y., Yuan, P., Wangbc, G. \& Xu, Q.H. (2013). $\mathrm{TiO}_{2}$ coated $\mathrm{Au} / \mathrm{Ag}$ nanorods with enhanced photocatalytic activity under visible light irradiation. Nanoscale 5, 4236-4241. DOI: 10.1039/C3NR00517H. 17. Ilieva, V., Tomovaa, D., Rakovskya, S., Eliyas, A. \& Li Puma, G. (2010). Enhancement of photocatalytic oxidation of oxalic acid by gold modified $\mathrm{WO}_{3} / \mathrm{TiO}_{2}$ photocatalysts under UV and visible light irradiation. J. Mol. Catal. A-Chem. 327(1-2), 51-57. DOI: 10.1016/j.molcata.2010.05.012.

18. Ohno, T., Akiyoshi, M., Umebayashi, T., Asai, K., Mitsui, T. \& Matsumura, M. (2004). Preparation of S-doped $\mathrm{TiO}_{2}$ photocatalysts and their photocatalytic activities under visible light. Appl. Cat. A-General 265(1), 115-121. DOI: 10.1016/j. apcata.2004.01.007.

19. Janus, M., Markowska-Szczupak, A., Kusiak-Nejman, E. \& Morawski, A.W. (2012). Disinfection of E. coli by carbon modified $\mathrm{TiO}_{2}$ photocatalysts. Environ. Prot. Eng. 38(2), 89-97. DOI: $10.5277 /$ epe 120208 .

20. Ohno, T., Sarukawa, K. \& Matsumura, M. (2001). Photocatalytic activities of pure rutile particles isolated from $\mathrm{TiO}_{2}$ powder by dissolving the anatase component in HF solution. J. Phys. Chem. B 105(12), 2417-2420. DOI: 10.1021/jp003211z. 21. Benabbou, A.K., Derriche, Z., Felix, C., Lejeune, P. \& Guillard, C. (2007). Photocatalytic inactivation of Escherischia coli: Effect of concentration of $\mathrm{TiO}_{2}$ and microorganism, nature, and intensity of UV irradiation. Appl. Cat. B: Environ. 76, 257-263. DOI: 10.1016/j.apcatb.2007.05.026.

22. Hu, C., Lan, Y., Qu, J., Hu, X. \& Wang, A. (2006). Ag/ $\mathrm{AgBr} / \mathrm{TiO}_{2}$ visible light photocatalyst for destruction of azodyes and bacteria. J. Phys. Chem. 110(9), 4066-4072. DOI: 10.1021/ jp0564400.

23. Shi, H., Li, G., Suna, H., Ana, T., Zhao, H. \& Wong, P.K. (2014). Visible-light-driven photocatalytic inactivation of $E$. coli by $\mathrm{Ag} / \mathrm{AgX}-\mathrm{CNTs}(\mathrm{X}=\mathrm{Cl}, \mathrm{Br}, \mathrm{I})$ plasmonic photocatalysts: Bacterial performance and deactivation mechanism. Appl. Cat.-B: Environ. 158-159, 301-307. DOI: 10.1016/j.apcatb.2014.04.033. 24. Hadrup, N. \& Lam, H.R. (2014). Oral toxicity of silver ions, silver nanoparticles and colloidal silver - A review. Regul. Toxicol. Pharmacol. 68(1), 1-7. DOI: 10.1016/j.yrtph.2013.11.002. 25. Kowalska, E., Wei, Z., Karabiyik, B., Herissan, A., Janczarek, M., Endo, M., Markowska-Szczupak, A., Remita, H. \& Ohtani, B. (2015). Silver-modified titania with enhanced photocatalytic and antimicrobial properties under UV and visible light irradiation. Cat. Today 252, 136-142. DOI: 10.1016/j. cattod.2014.10.038.

26. Sütterlin, S. (2015). Aspects of Bacterial Resistance to Silver. Dissertations from the Faculty of Medicine 1084. Uppsala Universitet.

27. Cheng, C.L., Sun, D.S., Chu, W.C., Tseng, Y.H., Ho, H.C., Wang, J.B., Chung, P.H., Chen, J.H., Tsai, P.J., Lin, N.T., Yu, M.S. \& Chang, H.H. (2009). The effects of the bacterial interaction with visible-light responsive titania photocatalyst on the bacteridical performance. J. Biom. Sci. 16(1), 7. DOI: 10.1186/1423-0127-16-7.

28. Choina, J., Dolat, D., Kusiak, E., Janus, M. \& Morawski, A.W. (2009). $\mathrm{TiO}_{2}$ modified by ammonia as a long lifetime photocatalyst for dyes decomposition. Pol. J. Chem. Technol. 11(4), 1-6. DOI: 10.2478/v10026-009-0035-9.

29. Bubacz, K., Choina, J., Dolat, D. \& Morawski, A.W. (2010). Methylene blue and phenol photocatalytic degradation on nanoparticles of anatase $\mathrm{TiO}_{2}$. Pol. J. Environ. Stud. 19(4), 685-691.

30. Nikaido, H. (2003). Molecular basis of bacterial outer membrane permeability revisited. Microbiol. Mol. Biol. Rev. 67(4), 593-656. DOI: 10.1128/MMBR.67.4.593-656.2003.

31. Jiang, J., Oberdorster, G., Elder, A., Gelein, R., Mercer, P. \& Biswas, P. (2008). Does nanoparticle activity depend upon size and crystal phase? Nanotoxicology 2(1), 33-42. DOI: 10.1080/17435390701882478.

32. Chen, D., Yang, D., Wang, Q. \& Jiang, Z. (2006). Effects of boron doping on photocatalytic activity and microstructure of titanium dioxide nanoparticles. Ind. Eng. Chem. Res. 45(12), 4110-4116. DOI: 10.1021/ie0600902.

33. Yang, Y., Zhong, H. \& Tian, C. (2010). Photocatalytic mechanisms of modified titania under visible light. Res. Chem. Intermed. 37, 91-102. DOI: 10.1007/s11164-010-0232-4. 